\title{
Gerakan Tuntas Zakat sebagai Refleksi Politik dalam Perolehan Zakat di Kabupaten Gorontalo
}

\author{
Syawaluddin S., Nur Fitri Aisyah \\ IAIN Sultan Amai Gorontalo \\ Email: Syawaluddin21@gmail.com;nfachaca95@gmail.com
}

\begin{abstract}
The commandment of zakat in Islam has a very noble social meaning because it is related to human relationships. This research is a field research with a qualitative method approach and is analyzed descriptively qualitatively. The data collection techniques are observation, interview and documentation. The results showed that Gerakan Tuntas Zakat program carried out by the Gorontalo District Government instructed all Regional Government Work Units to collect zakat in the amount of $2.5 \%$ of net income according to regulations. The movement to collect zakat has succeeded in having a significant impact on the increase in the amount of zakat obtained in Gorontalo District. However, the movement to collect zakat does not have an impact in the long run, it is evident that the increase in zakat earnings is not as much as during the launching period of the zakat movement, even though it has the potential to continue to experience growth. Increasing awareness, understanding and strengthening the politics of local governments will always be the key to success.
\end{abstract}

Keywords: Zakat, Politic, Nasional Zakat Agency, Gorontalo District Government

\section{Gerakan Tuntas Zakat as a Political Reflection in Obtaning Zakat in Gorontalo District}

\begin{abstract}
Abstrak: Perintah zakat dalam ajaran Islam memiliki makna sosial yang sangat mulia karena terkait hubungan dengan manusia. Penelitian ini adalah penelitian lapangan dengan pendekatan metode kualitatif dan dianalisis secara deskriptif kualitatif. Adapun teknik pengumpulan data berupa pengamatan, wawancara dan dokumentasi. Hasil penelitian menunjukan bahwa program Gerakan Tuntas Zakat yang dilakukan Pemerintah Kabupaten Gorontalo menginstruksikan kepada seluruh Satuan Kerja Pemerintah Daerah untuk melakukan pengumpulan zakat sejumlah 2,5\% dari pendapatan bersih sesuai regulasi. Gerakan mengumpul zakat telah berhasil memberikan dampak yang signifikan terhadap pertambahan jumlah perolehan zakat di Kabupaten Gorontalo. Namun, gerakan mengumpul zakat tidak memberikan dampak dalam jangka panjang, terbukti bahwa kenaikan perolehan zakat tidak sebanyak di masa pencangan gerakan zakat tersebut, padahal secara potensial terus mengalami pertumbuhan. Peningkatan kesadaran, pemahaman serta penguatan politik dari pemerintah daerah akan selalu menjadi kunci kesuksesan.
\end{abstract}

Kata Kunci: Zakat, Politik, BAZNAS, Pemerintah Kabupaten Gorontalo 


\section{Gerakan Tuntas Zakat sebagai Refleksi Politik dalam}

Perolehan Zakat di Kabupaten Gorontalo

\section{A. Pendahuluan}

Ibadah zakat merupakan kewajiban yang sifatnya malliyah (materi) dan menjadi rukun Islam. Selain sebagai ibadah memiliki peran ganda dalam kehidupan manusia, zakat juga dapat menjadi sumber fiskal negara dan salah pilar utama sistem keuangan negara dalam syariat Islam, dimana konsep dan perintah zakat dapat menjelma menjadi instrumen yang representatif sebagai variabel penting dan utama dalam proses penyelenggaraan negara utamanya sebagai jaring pengaman sosial (social assurance), gerakan fisabilillah, dan instrumen dalam pencapaian tingkat pertumbuhan ekonomi makro serta kemapanan politik. ${ }^{1}$

Zakat dalam ajaran Islam dibagi dua jenis yaitu zakat māl dan zakat fitrah. Zakat adalah pranata keagamaan yang memiliki keterkaitan secara fungsional dengan upaya pemecahan masalah-masalah keummatan, seperti pengentasan kemiskinan, kesenjangan sosial akibat perbedaan dalam kepemilikan kekayaan dan lain sebagainya. ${ }^{2}$ Perintah zakat sesungguhnya mengusung dua fungsi yakni fungsi kemanusiaan dan ketuhanan, kedua fungsi tersebut akan mendekatkan manusia kepada penciptanya dan kepada sesama makhluk. Zakat dapat dimanfaatkan bagi kesejahteraan masyarakat terutama untuk mengentaskan masyarakat dari kemiskinan dan menghilangkan kesenjangan sosial, maka perlu adanya pengelolaan zakat secara profesional dan bertanggung jawab yang dilakukan oleh masyarakat bersama pemerintah.

Tujuan pengelolaan zakat dimaksudkan agar meningkatnya kesadaran masyarakat dalam menunaikan dan dalam pelayanan ibadah zakat, meningkatnya fungsi dan peran pranata keagamaan dalam upaya mewujudkan kesejahteraan masyarakat dan keadilan sosial. Pelaksanaan tata kelola zakat yang baik memerlukan beberapa upaya, antara lain: (1) upaya peningkatan pemahaman tentang filosofi perintah zakat, (2) upaya peningkatan kemampuan manajerial pengelola lembaga zakat, (3) upaya pengelolaan yang berbasis manajemen modern. Dengan pemahaman yang baik dari masyarakat Islam tentang perintah zakat akan menumbuhkan kesadaran pula untuk melaksanakannya, kemudian dengan peningkatan kesadaran tentu akan

\footnotetext{
${ }^{1}$ Husein As-Syahatah, Akuntasi Zakat (Jakarta: Pustaka Progresif, 2004), 3.

${ }^{2}$ Rahmawati A. Rasyid, "Studi Pengelolaan Zakat Fitrah di Kecamatan Tibawa Kab. Gorontalo," Skripsi (Gorontalo: Fakultas Syariah dan Ekonomi Islam, 2010), 2.
} 
meningkatkan jumlah zakat yang diperoleh lembaga pengelola zakat, di sinilah pentingnya pribadi yang soleh, bertanggungjawab dan profesional dari para pengelola zakat. $^{3}$

Dengan demikian salah satu tujuan zakat adalah mempersempit jurang perbedaan ekonomi di dalam masyarakat hingga kebatas seminimal mungkin (QS. atTaubah/9: 71). Ayat ini mengandung unsur-unsur penting bahwa zakat adalah sebuah kewajiban bagi setiap muslim laki-laki maupun perempuan, juga zakat memiliki fungsi sosial yaitu sebagai penolong bagi orang lain. Orang beriman yang mengeluarkan zakat berarti telah melaksanakan kewajiban zakatnya, sekaligus membantu orang lain yang kurang beruntung untuk memperoleh apa yang menjadi haknya.

Keberadaan zakat sebagai ibadah dapat mendatangkan untuk memerangi para pembangkang zakat dianggap murtad dan boleh diperangi meskipun dia muslim. ${ }^{4}$ Mengetahui alur tentang ke mana zakat harus dibayarkan, berapa jumlah yang harus dibayarkan dan ke mana zakat tersebut akan dan telah dimanfaatkan adalah hal penting untuk dilaksanakan oleh lembaga tata kelola zakat. Seorang wajib zakat dalam era digital seperti sekarang ini dapat dimanjakan dengan informasi digital sehingga memudahkan para wajib zakat (muzakki), sehingga menjadi sebuah keniscayaan bagi lembaga zakat untuk memenuhi tuntutan tersebut dengan menerapkan prinsip manajemen dalam bentuk digitalisasi. ${ }^{5}$

Dengan pola pelaksanaan manajerial zakat yang modern dapat mengikis sikap apatis dari sebagian masyarakat terlebih sikap tidak percaya pada lembaga tata kelola zakat. Dengan sistem perencanaan sampai pengawasan yang terukur dan sistematis menciptakan efektivitas organisasi. Oleh sebab itu perlu ditunjang juga oleh tenagatenaga yang profesional, kredibel dan amanah. Allah swt. telah menegaskan dalam Alquran tentang proses pengumpulan dan peruntukan zakat seperti QS At-Taubah/9: 60:

\footnotetext{
${ }^{3}$ Mursyidi, Akuntasi Zakat (Bandung: PT. Remaja Rosda Karya, 2003), 36.

${ }^{4}$ Gazi Inayah, Teori Komprehensif tentang Zakat dan Pajak (Yogyakarta: PT. Tiara Wacana Yogya, 2003), 25.

${ }^{5}$ M. Tasrifin, "Studi Pelaksanaan Pengelolaan Zakat di Lembaga Pengembangan Dana Umat Sultan Agung LPDU-Sa Semarang,” Skripsi (Semarang: Unisula, 2008), 89.
} 


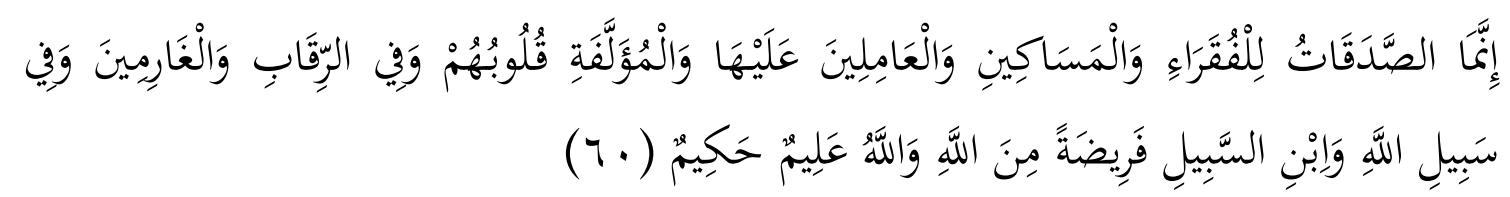

Terjemahnya:

Sesungguhnya zakat-zakat itu, hanyalah untuk orang-orang fakir, orang-orang miskin, pengurus-pengurus zakat, para mu'allaf yang dibujuk hatinya, untuk (memerdekakan) budak, orang-orang yang berhutang, untuk jalan Allah dan untuk mereka yuang sedang dalam perjalanan, sebagai suatu ketetapan yang diwajibkan Allah, dan Allah Maha mengetahui lagi Maha Bijaksana. ${ }^{6}$

Menelaah QS at-Taubah/9: 60 dapat dipahami bahwa pada setiap harta yang dimiliki oleh setiap manusia terdapat hak milik orang lain sehingga harus dikeluarkan, kemudian zakat yang disyariatkan kepada manusia memiliki peruntukan yang sudah ditentukan. Kelompok yang disebutkan didalam ayat tersebut menjadi prioritas dan tidak boleh diberiakn kepada kelompok diluar yang disebutkan. Adapun tata cara dan situasi dapat saja berkebang sesuai tuntunan piqhi modern yang merupakan pengembangan situasi yang tidak dijumpai dizama dahulu. ${ }^{7}$ Permasalahan yang menggejala saat ini adalah timbulnya kekhawatiran sebagian masyarakat, bahwa zakat yang mereka serahkan tidak akan sampai dan pengelolaannya tidak sesuai dengan tata kelola yang berlaku, fenomena ini menjadikan setiap pengelola zakat harus mampu menjawab kekhawatiran atau pandangan yang mengatakan bahwa pengurus saat ini mengalami krisis kepercayaan. Hal ini memberikan dampak pada masyarakat, masyarakat menyerahkan langsung zakatnya kepada mustahik yang mereka anggap memenuhi syarat yang biasanya adalah mereka fakir miskin, dan para gelandangan ditengah masyarakat. ${ }^{8}$

Pengelolaan zakat yang dilakukan secara profesional oleh organisasi zakat yang resmi membawa beberapa keuntungan, yakni (1) memastikan dan meningkatkan kedisiplinan dari wajib zakat (muzakki); (2) menempatkan posisi mustahiq pada tempat yang mulia tanpa harus merasa malu atau sedih dihadapan wajib zakat

${ }^{6}$ Kementerian Agama RI, Ummul Mukmin: Al-Qur'an dan Terjemahan untuk Wanita (Jakarta: Wali, 2010), 196.

${ }^{7}$ Ali Hasan, Zakat dan Infak (Jakarta: Kencana Prenada Media, 2005), 19.

${ }^{8}$ Departemen Agama RI, Pedoman Pengelolaan Zakat (Jakarta: Direktorat Pengembangan Zakat dan Wakaf, Ditjen Bimas Islam dan Penyelenggaraan Haji, 2004), 73. 
(muzakki); (3) memastikan terciptanya efektivitas dan berdaya guna serta tepat sasaran peruntukan dana zakat; (4) meningkatkan syi'ar Islam di tengah masyarakat; (5) menciptakan garis koordinasi yang baik sehingga akurasi data dapat dipertanggung jawabkan; (6) memastikan seluruh masyarakat dapat mengakses pelaporan zakat; (7) memposisikan muzakki dan mustahiq pada posisi yang sebenarnya sehingga tidak mendeskreditkan kelompok manapun. Fungsi zakat, terutama yang berkaitan dengan pemerataan dan kesejahteraan umat, akan sulit diwujudkan jika tidak dilakukan dengan baik dan benar. 9

Undang-Undang Nomor 23 Tahun 2011 tentang Pengelolaan Zakat mengamanahkan tata kelola zakat secara profesional yang dilakukan oleh lembaga zakat resmi yakni Badan Amil Zakat Nasional (BAZNAS) dan Lembaga Amil Zakat (LAZ). BAZNAS berdiri mulai tingkat kabupaten/kota hingga tingkat nasional. Pada tingkat nasional BAZNAS memiliki fungsi koordinatif dengan daerah, fungsi lembaga ini adalah fungsi regulator sekalian operator. Demi terciptanya lembaga zakat yang baik dan profesional maka pemerintah terus mendorong untuk menjalankan fungsi sebagaimana amanah undang-undang. ${ }^{10}$

Ini menunjukkan bahwa dalam upaya peningkatan kesadaran dan kedisipilinan masyarakat dalam membayar zakat memerlukan sebuah upaya berupa effort serta motivasi yang kuat sesuai syariat Islam. Saat ini mungkin dapat kita katakan bahwa proses dan metode pengelolaan zakat modern baru dapat dijumpai pada masyarakat perkotaan dengan mengambil prinsip manajemen yang baik pula, sedangkan di wilayah luar perkotaan metode dan prosesnya masih berbasis pada kearifan lokal, yakni menyerahkan zakat secara langsung, jika tidak maka akan diserahkan pada seseorang/individu yang ditokohkan dan sifat serta karakteristiknya diserahkan pada diri masing-masing. Oleh sebab itu untuk mencapai harapan menuju tata kelola zakat modern maka diperlukan kebersamaan dalam memahami, mengamalkan serta mengedukasi setiap umat Islam.

\footnotetext{
${ }^{9}$ Abdurrahman Qadir, Zakat dalam Dimensi Mahdah dan Sosial (Jakarta: Raja Grafindo Persada, 1988), 85.

${ }^{10}$ Gustian Djuanda, Pelaporan Zakat Pengurang Pajak Penghasilan (Jakarta: PT. Raja Grafindo PERSADA, 2006), 3 .
} 
Agar dapat merealisasikan pemanfaatan zakat yang berdayaguna dalam jangka panjang tentu tidaklah mudah, sertidaknya masih dijumpai beberapa kendala teknis, diantaranya: Kesatu, masih rendahnya tingkat kedermawanan para wajib zakat untuk menunaikan kewajibannya, meskipun secara jelas memiliki harta yang cukup bahkan lebih untuk melaksanakannya; Kedua, disaat kepercayaan dan kejujuran menjadi elemen kunci pada penyelenggaraan tata kelola zakat, realitas masyarakat umumnya belum memberikan hal tersebut kepada sebagian besar asumsi masyarakat yang masih meragukan kredibilitas penyelenggara tata kelola zakat, hal ini tidak terlepas dari tingginya angka kasus korupsi di tanah air. Hal ini memberikan pengaruh yang signifikan terhadap pandangan masyarakat terhadap kepercayaan mereka pada pengurus lembaga zakat; Ketiga, sebagai ibadah yang terus mengalami perkembangan pada konten perintah dan jenisnya, dalam piqhi moder tentu juga mengalami perkembangan. Bukan masalah wajib atau tidaknya perintah zakat melainkan perkembangan jenis zakat, zakat profesi misalnya oleh para ahli piqhi berbeda pendapat dalam menerjemahkannya, hal karena pada zaman dahuku belum dikenal dengan sebutan zakat profesi tersebut. Megingat potensi zakat pada jenis zakat ini maka menjadi penting untuk menempatkan pada dimensi hukum syariatnya. Oleh sebagian besar ahli fikih memberikan kiyas terhadap zakat pertanian, yakni jika telah sampai nisabnya maka menjadi wajib untuk ditunaikan. ${ }^{11}$

Sebagai negara dengan umat muslim terbesar di dunia, Indonesia memiliki potensi zakat yang besar pula, faktanya bahwa potensi tersebut masih jauh dari realitas yang ada. Oleh sebagaian besar penelitian mengungkapkan beberapa aspek yang mungkin jadi penyebabnya, selain kesadaran, pengetahuan hingga tata kelola lembaga zakat. Argumentasi ini tentu beralasan mengingat kondisi geografis bangsa Indonesia dengan ribuan suku dan etnis serta budaya, memberikan edukasi dan penyadaran baukanlah hal mudah, butuh kesabaran, ketekunan dan kesungguhan. Belum lagi jika dilihat dari aspek politiknya, keragaman ini ini akan semakin kompleks permasalahannya. Tetapi satu hal yang penting adalah bahwa masyarakat Indonesia

\footnotetext{
${ }^{11} \mathrm{http}: / /$ www.beritasatu.com/blog/ekonomi/2764-optimalisasi-pengelolaan-dan-\%09regulasizakat.html, diakses 5Januari 2020.
} 
merupakan bangsa yang senantiasa taat dan kritis pada pemimpinnya, dari aspek inilah menjadi hal menarik untuk dikaji pada artikel ini.

Jika dilakukan telaah lebih mendalam tentang potensi yang besar zakat Indonesia, terdapat fenomena yang lain yang isa dilihat, misalnya apakah memang masyarakt yang berada pada kelompok yang telah teredukasi atau belum telah mampu menteteksi dalam menempatkan dirinya sebagai orang atau institusi yang sudah wajib zakat atau belum, sehubungan dengan ini maka informasi yang akurat dan akuntabel menjadi kunci utama. Dengan sistem informasi yang baik seseorang dapat diingatkan akan posisi sebagai wajib zakat atau belum, dengan memanfaat media sosial. ${ }^{12}$ UU No. 23 Tahun 2011 telah memerikan dasar hukum yang kuat pada tatanan lembaga zakat di Indonesia, regulasi ini diharapkan dapat mendorong pertumbuhan zakat di tanah air, demikian juga dengan pengelolaan zakat di tingkat provinsi, kabupaten/kota.

Revitalisasi dan optimalisasi zakat dapat ditempuh melalui penguatan tata kelola zakat, penguatan kelembagaan organisasi zakat, penguatan regulasi dan penegak kan hukumnya, termasuk perlunya dukungan politik dan penguatan pengawasan zakat. Pemerintah sebagai regulator dalam tata kelola zakat dapat memberikan kepastian dalam penyelenggaraan tata kelola zakat dilakukan dengan baik dan benar. dengan perolehan zakat yang terus membaik maka akan semakin banyak pula mustahik yang dapat dibantu, secara tidak langsung memberikan dukungan terhadap program pemerintah dalam menanggulangi kemiskinan. ${ }^{13}$

Sebagai ibadah yang mengusung terciptanya stabilitas sosial yang aman dan tenteram, serta memposisikan manusia diatas manusia lainnya menjadi sama rata, sudah selayaknya jika harus didukung oleh seluruh lapisan masyarakat utamnya pemerintah sebagai pemegang kendali kebijakan. Kebijakan adalah merupakan kunci pokok penyelenggaraan UU No. 23 Tahun 2011 tersebut, hal ini tentu butuh dukungan politik dapat dilihat beberapa daerah yang memiliki capaian zakat yang baik pasti ditunjang oleh apreseasi politik kekuasaan oleh pemerintah. BAZNAS Kabupaten Gorontalo adalah organisasi resmi pemerintah yang terbentuk sesuai dengan

\footnotetext{
${ }^{12}$ Djuanda, Pelaporan Zakat, 2.

${ }^{13} \mathrm{http}: / /$ www.beritasatu.com/blog/ekonomi/2764-optimalisasi-pengelolaan-dan-\%09regulasizakat.html, diakses tanggal 5 Januari 2020.
} 
Keputusan Dirjen Bimas Islam No. DJ.II/568 Tahun 2014 tentang Pembentukan BAZNAS Kabupaten/Kota di Indonesia dan Pembentukan Pimpinan BAZNAS Kabupaten Gorontalo ditetapkan dengan SK Bupati Kabupaten Gorontalo No. 538/01.4/VIII/2015, tertanggal 28 Agustus 2015.

Dengan demikian BAZNAS Kabupaten Gorontalo memiliki dasar hukum dan legalitas yang kuat untuk melaksanakan kegiatan Pengelolaan Zakat di Kabupaten Gorontalo. Selanjutnya pemerintah berperan dalam menguatkan badan tersebut sebagai wujud manisvestasi penyelenggaraan pemerintahan daerah yang komprehenshif dan tidak terpisahkan dari bagian pemerintahan Kabupaten Gorontalo. Sebelumnya masih dirasakan seakan-akan Organisasi Pengelolaan Zakat berjalan sendiri-sendiri. Oleh sebab itu perlunya peningkatan sinegritas dengan BAZNAS Pusat, BAZNAS Provinsi dan BAZNAS Kabupaten Gorontalo dan tak kala pentingnya dengan Pemerintah Kabupaten Gorontalo untuk menguatkan kedudukan Organisasi Pengelolaan Zakat dan Peran BAZNAS Kabupaten Gorontalo. ${ }^{14}$

Kabupaten Gorontalo adalah wilayah dengan mayoritas penduduk beragama Islam, yakni kurang lebih 98\%. Pertumbuhan ekonomi Kabupaten Gorontalo terus meningkat hingga mencapai angka pertumbuhan rata-rata ekonomi secara nasional dan kelas menengah Kabupaten Gorontalo terus bertambah menjadikan potensi zakat di Kabupaten Gorontalo juga secara potensial turut meningkat. Untuk menopang hal tersebut maka Pemerintah Daerah melalui BAZNAS Kabupaten Gorontalo telah mencanangkan program “Gerakan Tuntas Zakat” yang dicanangkan di Mesjid Agung Baiturrahman Limboto tepat pada Hari Ahad tanggal 02 Oktober 2016, yang menginstruksikan kepada seluruh Satuan Kerja Pemerintah Daerah (SKPD) untuk melakukan pengumpulan zakat sejumlah 2,5\% dari pendapatan bersih sesuai Peraturan Bupati (Perbup) Kabupaten Gorontalo No.1 Tahun 2016 mengenai tata cara pengumpulan zakat di lingkungan pemerintah Kabupaten Gorontalo.

Hasil Perolehan Zakat dan Infak BAZNAS Kabupaten Gorontalo pada tahun 2015 semester 1 sebesar Rp 464.924.594,2 dan semester 2 sebesar Rp 505.703.538 dengan jumlah muzakki sebanyak 3.208 orang; pada tahun 2016 semester 1 sebesar Rp

\footnotetext{
${ }^{14}$ Badan Amil Zakat Nasional Kabupaten Gorontalo, Rencana Strategis Badan Amil Zakat Nasional Kabupaten Gorontalo 2015-2020.
} 
712.249.321,4 dan semester 2 sebesar Rp 830.599.855,9 dengan jumlah muzakki sebanyak 3.208 orang; pada tahun 2017 semester 1 sebesar Rp 1.033.060.642,- dan semester 2 sebesar Rp 1.317.296.625,- dengan jumlah muzakki sebanyak 1.460 orang, dan tahun 2018 semester 1 sebesar Rp 1.005.945.533 dan semester 2 sebesar Rp 1.199.820.473 dengan jumlah muzakki sebanyak 2724 orang. ${ }^{15}$

Segi penerimaan zakat di BAZNAS Kabupaten Gorontalo setiap tahunnya mengalami peningkatan, hal ini tidak lepas dari usaha pihak BAZNAS dengan mensosialisasikan tentang urgensi zakat dan terjun langsung dalam hal pengumpulan zakat untuk memberikan kemudahan pada muzakki. Peningkatan perolehan zakat yang sangat signifikan ditunjukkan di tahun 2017 yakni berjumlah 54,42\% dibanding tahun 2016, hal ini terjadi karena program gerakan tuntas zakat baru dilaksanakan mulai akhir tahun 2016. Kenaikan yang sangat signifikan memberikan perbedaan yang sangat berarti, sebelum dan sesudah adanya intervensi politik pemerintah.

\section{B. Zakat Perspektif Hukum Ekonomi Syariah}

Kata zakat jika dilihat dari sudut bahasa, bermakna annama' yang berarti kesuburan, thaharah berarti kesucian, barakah artinya berkah dan juga bermakna tazkiyah, artinya mensucikan. Al-Imam An-Nawawi mengatakan bahwa zakat mengandung makna kesuburan. ${ }^{16}$ Mazhab Syafi'i berpendapat zakat merupakan ungkapan jiwa untuk mengeluarkan sebagian harta yang dimiliki yang memenuhi nisab dari hak kepemilikan melalui cara dan ketentuan khusus. Mazhab Hanbali menyebutkan zakat merupakan hak dari harta yang wajib untuk dikeluarkan yang berasal dari harta yang khusus yang diperuntukkan juga untuk kelompok yang khusus pula. ${ }^{17}$ Kata zakat dalam Alquran disebutkan secara ma'arifah, 8 kali diantaranya terdapat dalam surah Makkiyah, dan selainya terdapat dalam surat-surat Madaniyah.

\footnotetext{
${ }^{15}$ Ibid.

${ }^{16}$ Teungku Muhammad Hasbi Ash-Shiddieqy, Pedoman Zakat (Semarang: PT. Pustaka Rizki Putra, 2006), 3.

${ }^{17}$ Wahbah Al-Zuhayly, Zakat Kajian Berbagai Mazhab (Bandung: Remaja Rosdakarya, 2005), 84.
} 
Kata zakat terdapat dalam Alquran bersama kata salat dan bergandengan secara langsung kurang lebih di 28 tempat. $^{18}$

Zakat mempunyai enam prinsip, yaitu: Pertama, prinsip keyakinan keagamaan menyatakan bahwa orang yang membayar zakat menyakini bahwa pembayaran tersebut merupakan salah satu meninvestasi keyakinan agamanya, sehingga kalau orang bersangkutan belum menunaikan zakatnya, belum merasa sempurna ibadahnya; Kedua, distribusi kekayaan dan kesejahteraan dalam konsep ekonomi modern telah lama menjadi prinsip dalam ibadah zakat yakni keadilan dan pemerataan, dengan filosinya bahwa didalam harta orang yang mampu terdapat harta orang yang tidak mampu; Ketiga, harta yang berkembang atau memiliki produktivitas dalam produksi tertentu harus dikeluarkan zakatnya, tentu jika telah sampai pada jangka waktu yang ditentukan dalam syariat Islam; Keempat, ibadah zakat juga memegang prinsip bahwa perintah hanya boleh dilakukan bagi orang memiliki kesehatan yang baik, sehingga dengan kesehatan yang dimiliki seseorang dapat membedakan hal yang baik dan benar, barulah hukum tersebut dapat berlaku padanya, artinya orang tidak sehat secara rohani tidak kena ketentuan tersebut. ${ }^{19}$

Zakat sebagai sebuah perintah atau ibadah yang telah ditetapkan kadarnya oleh Allah swt. dan diatur mekanismenya oleh pemerintah berdasarkan syariat, sehingga perintah dengan otoritas yang dimilikinya dapat menarik bahkan memaksakan kepada muzakki yang telah memenuhi persyaratan secara syariat. Zakat sebagaimana diatur dalam ketentuan syariat diamanahi untuk memenuhi hak dari golongan yang sudah diatur didalam Alquran. Selain itu dapat juga digunakan untuk pemenuhan kebutuhan politik negara sebagai sumber fiskal.

Ash-Shiddieqy memberikan batasan-batasan tentang unsur-unsur zakat antara lain:

1. Zakat merupakan perintah wajib yang berupa materi, yang dapat bayarkan baik berupa barang maupun uang tunai, sehingga dalam konteks ekonomi zakat sesungguhnya ibadah yang menitikberatkan pada aspek material yang bertujuan untuk distribusi pendapatan anata satu muslim dengan muslim lainnya.

\footnotetext{
${ }^{18}$ Ash-Shiddieqy, Pedoman Zakat, 5.

${ }^{19}$ Al-Zuhayly, Zakat Kajian Berbagai Mazhab, 84.
} 
2. Zakat merupakan ibadah yang telah ditetapkan syarat dan ketentuannya, sehingga akan mengikat bagi seorang muslim artinya menjadi sebuah keharusan yang dengan harta tersebut akan memperoleh keberkahan dari Allah swt..

3. Zakat merupakan ibadah yang didalamnya terdapat perintah untuk menunaikan secara kelembagaan, artinya perlu dan harus ada keterlibatan pemerintah. Hal ini dimaksudkan agar timbul kepatuhan dengan adanya intervensi pemerintah, selain itu kelembagaan dimaksudkan timbul adanya keteraturan dan ketaatan baik oleh muzakki maupun mustahiq.

4. Zakat merupakan perintah atau kewajiban yang didalamnya sudah tidak ada lagi perdebatan mengenai kewajibannya, sehingga tidak ada lagi yang bisa melakukan penolakan. Bahkan sekalipun yang bertindak sebagai pembayar dan pengelola zakat merupakan orang-orang yang mungkin terindikasi durhaka atau zalim.

5. Zakat merupakan perintah yang dalam pelaksanaannya tidak terdapat imbalan atau konvensasi selain yang telah diatur hak dari masing-masing pihak berdasarkan syariat Islam. Hukum Islam tidak mensyaratkan adannya imbalan kemanfaatan antara umat Islam yang miskin dan golongan yang berhak (asnaf). Hal ini dimaksudkan untuk mengangkat derajat manusia dihadapan manusia lainnya.

6. Zakat adalah kewajiban tuntutan politik untuk keuangan Islam. Alokasi atau peruntukkan zakat telah ditetapkan Alquran. Jika hukum ekonomi telah membatasi sasaran pajak untuk menutupi kebutuhan pangan, maka sesungguhnya ekonomi Islam tidak mengacu seperti itu, lebih tinggi kedudukan hukumnya dalam mengalokasikan zakat, ekonomi Islam berusaha mewujudkan tujuan-tujuan ekonomi, keuangan sosial, dan politik, yaitu:

a. Berkaitan dengan tujuan-tujan ekonomi, zakat emas, perak, atau sejenisnya.

b. Berkaitan dengan tujuan keuangan, zakat dimaksudkan sebagai devisa negara (baitul mal) yang dimaksudkan untuk pemenuhan kebutuhan pokok manusia yang dibutuhkan, yakni kebutuhan pangan fakir miskin, ibnu sabil, gharim, dan riqab, juga untuk memenuhi kebutuhan pangan yang lain seperti untuk dakwah agama, membangun mesjid, dan sebagainya. 
c. Berkaitan dengan tujuan sosial, zakat diarahkan untuk mewujudkan cita-cita sosial. Zakat adalah bagian terpenting dari komponen keuangan politik Islam dalam mewujudkan cita-cita sosial, seperti jaminan sosial dan solidaritas sosial.

d. Berkaitan dengan tujuan politik, zakat diarahkan untuk melunakkan hati orang lain dari berbuat jahat. Zakat 10\% dari pembangkang zakat yang diperangi dipergunakan untuk kekuatan politik negara Islam. ${ }^{20}$

Sesuai dengan amanah UU No. 23 Tahun 2011 dan QS at-Taubah/9: 60 bahwa pengelolaan zakat sebetulnya mesti diselenggrakan oleh negara melalui lembaga independen yang diberi mandat oleh negara. Selanjutnya lembaga ini yang akan melakukan amanah tata kelola zakat, sebagai perwakilan pemerintah yang mengurusi pemungutan dan distribusi zakat. ${ }^{21}$ Dengan demikian diharapkan akan membawa dampak positif, tidak hanya dari segi pengumpulan zakat akan tetapi dalam memperbaiki tatanan kehidupan ekonomi umat, kemudian juga diharapkan adalah peningkatan efektifitas tata kelola zakat karena tidak lagi dilakukan secara parsial oleh kelompok-kelompok kecil atau individu ke individu. Pola koordinasi antar lembaga nampaknya lebih mudah dilakukan sehingga tidak akan ditemui distribusi ganda, maksudnya seorang mustahik dapat zakat dari dua lembaga karena tidak adanya koordinasi. Agar supaya umat Islam dapat menunuaikan zakat secara aman dan terpercaya maka di terbitkan regulasi tentang zakat, salah satunya adalah UU No. 23 Tahun 2011. Di samping itu, undang-undang juga memberi peluang kepada amil zakat swasta untuk mengumpulkan zakat dan mendistribusikan zakat dengan syarat dan ketentuan yang diatur lebih lanjut oleh Menteri Agama RI.

Penataan lembaga zakat harus dilihat dari dua skala prioritas yang berbeda tetapi saling berkaitan satu sama lain, yaitu: Pertama, bagian yang dapat dilakukan sendiri oleh lembaga amil zakat yaitu hal-hal yang bersifat teknis dan mikro; Kedua, wilayah yang menjadi domain pemerintah tentu ini menyangkat pada hal lebih bersifat makro dan fundamental. Hal ini bukan bermaksud agar aktivitas dan kesempatan

\footnotetext{
${ }^{20}$ Ash-Shiddieqy, Pedoman Zakat, 5.

${ }^{21}$ Mahmud Huda, "Peran Pemerintah dalam Pengelolaan Zakat Menghadapi Pasar Tunggal Asean 2015,” Prosiding Seminas Competitive Advantage, Vol. 1 No. 1, 2011; 2.
} 
masyarakat untuk mengelola zakat menjadi terbatas atau hilang sama sekali, tetapi lebih dimaksudkan pada kesatuan langkah yang terkoordinasi secara nasional. Bukankah suatu persoalan jika dipikirkan dan dilaksanakan secara bersama, terencana dan sistematis akan membawa dampak yang lebih maksimal. Tata kelola zakat pemerintah memiliki peran, yaitu: pemerintah dapat bertindak sebagai regulator dan operator tunggal, juga pemerintah boleh memainkan peran sebagai eksekutor atau pengawas yang dapat memberikan sangsi terhadap setiap orang yang enggan untuk menjalankan kewajiban zakat. ${ }^{22}$

Alquran dan Sunnah telah menjelaskan posisi pemerintah dalam urusan zakat, misalnya QS at-Taubah/9: 60 dan 103. Sedangkan sunnah Rasulullah sebagai yang diperintahkan kepada Muaz bin Jabal ra.:

Apabila merka patuh kepadamu untuk hal itu (bersyahadat), maka beritahukanlah kepada mereka bahwa Allah mewajibakan zakat kepada merka pada harta mereka yang diambil dari orang kaya di antara mereka, lalu dikembalikan kepada yang fakir miskin di antara mereka (HR. Bukhari). ${ }^{23}$

Huda mengemukakan sebagaiman dikutip dari pendapat Ibnu Hajar al-Asqalani bahwa imam adalah orang yang melaksanakan pemungutan dan pembagian zakat, baik dengan langsung maupun melalui wakilnya; barangsiapa yang membangkang, maka zakat akan diambil dengan paksa. ${ }^{24}$ Sesuai perannya, pemerintah sebagai operator juga sebagai eksekutor terhadap setiap pembangkangan perintah zakat, tentu dilakukan berdasarkan peraturan yang teah dbuat. Jika itu akan dilakukan maka setidaknya sanksi yang dijatuhkan kepada setiap pembangkan zakat dapat melihat kondisi-kondisi berikut ini:

1. Seseorang yang tidak menunaikan kewajiban zakat dikarenakan ketidaktahuannya, maka tidak dikenai sanksi takzir. Oleh sebab itu pemerintah dapat menyampaikan tentang kewajibannya lalu serta merta mengambilnya.

2. Seseorang yang dengan sengaja melakukan pembangkangan atau pengingkaran terhadap kewajibannya, maka ia dianggap murtad dan diperlakukan sebagai orang murtad. Pertama-tama dia akan diminta taubat (kembali masuk Islam), jika tidak

\footnotetext{
${ }^{22}$ Ibid., 3 .

${ }^{23}$ Imam Asy-Syaukani, Nailul Authar (Bairut: Dar Ibn Hazm, 2000), 792.

${ }^{24}$ Mahmud Huda, "Peran Pemerintah dalam Pengelolaan Zakat," 5.
} 
mau bertaubat, maka pemerintah menjatuhkan hukuman mati kepadanya dan hartanya menjadi hak baitul mal (kas negara).

3. Seseorang yang dengan sengaja tidak membayar zakat, akan tetapi tetap mempercayai zakat sebagai sebuah kewajibannya, maka kelompok inilah yang boleh dilakukan pemungutan atau pengambilan paksa, dan jika mereka merupakan komunitas (kelompok) yang tidak mau menunaikan kewajiban zakatnya, maka mereka akan diperangi pemerintah dan diperlakukan sebagai pemberontak (bughat). Hal ini seperti dilakukan Khalifah Abu Bakar ash-Shiddiq. ${ }^{25}$

\section{Komitmen Politik sebagai Upaya Penguatan BAZNAS di Kabupaten Gorontalo}

Pemerintah daerah sebagai perpanjangan kewenangan pemerintah pusat berperan dalam melakukan fungsi pengawasan regulasi yang memiliki peranan penting, akan tetapi selain fungsi tersebut selama ini masih dianggap banyak menyisakan berbagai masalah karena fungsi tersebut belum dapat dijalankan secara optimal, katakanlah misalnya memperkuat network antar lembaga, melakukan standarisasi kelembagaan dan melakukan pengawasan dan pembinaan serta terencana, terukur dan sistematis, sehingga fungsi regulator tersebut efektif.

Untuk dapat mengimplementasikan isi undang-undang atau peraturan pemerintah tidak cukup dengan hanya memberikan dukungan, tetapi juga menyediakan fasilitas untuk terselenggaranya isi undang-undang atau peraturan tersebut. Salah satu tantangan dalam isi UU No. 23 Tahun 2011 adalah ketika zakat itu diposisikan pada kewajiban yang bersifat sukarela, hal ini tentu memberikan bias kepada masyarakat karena ibadah wajib tapi pelaksanaannya bersifat sukarela, ditambah tidak adanya sangsi terhadap mereka yang tidak menunaikannya (punishment) yang diterima bila tidak bayar zakat, dan tidak pula ada insentif (reward) yang didapat bila bayar zakat.

Terkait dengan masalah tersebut, seharusnya pemerintah dapat mengendalikan melalui regulasi yang kuat sehingga benar-benar dapat memaksimalkan potensi zakat pada tiap-tiap daerah secara khusus dan nasional pada umumnya dengan cara merubah

${ }^{25}$ Abdul Qadim Zallum, Al-Amwal fi Dawlah al-Khilafah (Bairut: Darul 'Ilmi li al-Malayin, 1983), 188. 
atau memperkuat fungsi regulator. Amandemen undang-undang atau penguatan undang-undang di tingkat provinsi, kabupaten/kota hingga tingkat kecamatan sangatlah perlu dilakukan mengingat saat ini masyarakat masih menganggap bahwa zakat merupakan pranata yang sifatnya kesukarelaan. Tentu hal tersebut memang perlu adanya campur tangan yang nyata dari pihak pemerintah yakni dengan cara memberikan atau mengeluarkan regulasi yang lebih spesifik lagi sehingga masyarakat sebagai muzakki tidak enggan lagi untuk menunaikan zakat di tingkat Unit Pengumpul Zakat (UPZ).

Gerakan mengumpul zakat yang dicanangkan di Masjid Agung Baiturrahman Limboto oleh Pemerintah Kabupaten Gorontalo dimaksudkan untuk mendukung eksistensi lembaga BAZNAS Kabupaten Gorontalo. Hal ini dianggap sebagai langkah efektif membantu pemerintah dalam menangani kemiskinan. Hakikat zakat sama dengan fungsi yang diemban pemerintah, yakni sama-sama bertujuan meringankan beban hidup masyarakat. Penyaluran zakat diatur dalam Alquran dan hadis Nabi saw., olehnya itu BAZNAS pun diatur dalam undang-undang. Fungsi zakat itu membantu kaum dhuafa, sama tujuannya dengan pemerintahan, meningkatkan kualitas hidup masyarakat.

Juga bahwa tingkat kesejahteraan atau kemapanan masyarakat Kabupaten Gorontalo belum merata, sehingga dipandang perlu untuk melakukan pemberdayaan lembaga zakat sebagai win-Win solution, melakukan sosialisasi tentang gerakan ini agar beroleh tanggapan seluruh kalangan masyarakat, khususnya Aparatur Sipil Negara (ASN) karena mereka yang menerima gaji dari Pemerintah Daerah, jika ikhlas menyalurkan zakat langsung disisihkan sebagian kecil dari gajinya ke rekening BAZNAS. Selain itu Pemda Kabupaten Gorontalo kini menerbitkan Peraturan Bupati (Perbup) yang secara garis besar mengatur teknis tentang penghimpunan dan pendistribusian zakat oleh BAZNAS Kabupaten Gorontalo.

Kesemua komitmen politik ini ditujukan agar institusi BAZNAS akan lebih optimal menyentuh kebutuhan ekonomi kaum dhuafa. Bahkan untuk sosialisasi gerakan tersebut telah diadakan ribuan lembar stiker yang dapat memberikan informasi tentang tahapan pembayaran zakat melalui rekening BAZNAS Kabupaten Gorontalo. 
Kegiatan sosialisasi gerakan mengumpul zakat di Kabupaten Gorontalo dihadiri oleh seluruh elemen masyarakat yang pada waktu itu disiarkan secara langsung oleh Radio Republik Indonesia (RRI) Gorontalo yang bertempat di Caffe Trisakti saat itu, dengan sambutan hangat dari berbagai kalangan yang aktif menyampaikan pandangannya melalui dialog interaktif. Bahkan ketika program tersebut mulai dijalankan, masyarakat berharap BAZNAS harus lebih transparan dalam penyaluran zakat karena program tersebut efektif membantu pemerintah untuk mengurangi jumlah penduduk miskin di Kabupaten Gorontalo. Dengan demikian nampak jelas bahwa adanya komitmen politik pejabat atau pemerintah akan memberikan dampak yang signifikan terhadap perolehan zakat, komitmen ini jika dapat dilakukan secara konsisten dan terencana tentu akan memberikan efek baik dalam jangka panjang.

Selain itu juga, rendahnya pengetahuan masyarakat tentang fikih zakat menjadi kendala tersendiri ditengah peningkatan peran BAZNAS yang berbasis pada komitmen politik pemerintah daerah. Gerakan zakat yang dicanangkan oleh pemerintah daerah dimaksudkan untuk memberikan penguatan posisi lembaga BAZNAS ditengan masyarakat. Namun kendala kecilpun ikut mewarnai upaya penguatan BAZNAS tersebut, misalnya sebagaian masyarakat masih memandang bahwa zakat hanya terbatas pada zakat fitrah, yang hanya dikeluarkan di bulan Ramadhan, adanya pandangan bahwa membayar zakat secara langsung kepada mustahik adalah yang terbaik dan telah menjadi tradisi pada sebagian besar masyarakat di Kabupaten Gorontalo, masyarakat lebih senang menunaikan zakatnya secara langsung kepada mustahik dalam bentuk bantuan konsumsi seperti makanan dan minuman.

Oleh sebab itulah, tata kelola zakat mesti diupayakan untuk selalu dapat menggunakan fungsi-fungsi manajemen yang memegang prinsip perencanaan (planning), pengorganisasian (organitation), pelaksanaan (actuiting) dan pengarahan serta pengawasan (monitoring). Dalam lembaga zakat ada tiga kegiatan utama, yakni penghimpunan, pengelolaan dan pendayagunaan. Ketiganya dimasukkan dalam tiga divisi utama, yaitu divisi penghimpunan, divisi keuangan dan divisi pendayagunaan.

Untuk melakukan pemungutan zakat dari para wajib zakat dilakukan dengan beraneka kegiatan, hal ini berikan kepada masing-masing tim untuk melakukan inovasi 
dalam mengembangan program tersebut. Program ini dapat ditawarkan sebagai kerjasama program dengan perusahaan dan lembaga yang lain. Pada prinsipnya muzakki dapat dikelompokkan dalam dua kelompok, yakni:

1. Muzakki yang telah terdaftar identitasnya pada BAZNAS dan dengan teratur menyerahkan zakatnya, disebut sebagai muzakki tetap. Kelompok ini tidak hanya individu tetapi juga kelompok atau institusi.

2. Muzakki yang tidak tercatat pada database BAZNAS akan tetapi menyerahkan dana zakatnya secara tidak teratur atau temporer, disebut muzakki temporare. Kelompok ini biasanya melakukan pembayaran zakat tidak pada satu lembaga akan tetapi berpindah-pindah lembaga zakat. Kelompok inilah yang paling baik didekati dengan berbagai inovasi rencana program oleh LPZ.

Untuk melakukan penggalangan dana zakat, kegiatan-kegiatan yang telah dilakukan oleh BAZNAS Kabupaten Gorontalo, antara lain:

1. Melakukan kampanye; layaknya sifat kampanye umumnya adalah berusaha untuk menarik simpatik masyarakat untuk menyetorkan zakatnya, sekalian melakukan edukasi kepada masyarakat yang belum paham tentang seluk beluk zakat. Kampanye ini juga telah dibuat panduan tentang tujuan, penggunaan metode, materi kampanye, media bahkan sarana kampanye.

2. Kerjasama program untuk lebih mengembangkan network maka dilakukan pula kerjasama dengan lembaga luar yang dipandang prospek untuk pengembangan penggalangan zakat.

3. Seminar dan diskusi yang bertujuan untuk sosialisasi dan memberikan pemahaman masyarakat tentang hukum, potensi dan manfaat zakat. Tema yang diangkat, momen serta nara sumber sangat mempengaruhi partisipasi masyarakat untuk mengikuti.

Selain kegiatan tersebut juga dilakukan pemberdayaan layanan perbankan, yaitu untuk menciptakan suasana kenyamanan dalam transaksi pembayaran zakat dengan jasa layanan bank. Tujuannya adalah mempermudah muzakki melakukan pembayaran dan pendistribusian zakat kepada mustahiq. Layanan muzakki BAZNAS Kabupaten Gorontalo dalam Gerakan Tuntas Zakat yang dimaksudkan untuk memudahkan, yaitu: 
1. Penghimpunan dana, terdiri dari unit pengumpulan dana zakat, kerjasama program bina lingkungan (CSR), dan donasi pelanggan/retail,

2. Layanan pembayaran, terdiri dari transaksi zakat, infaq dan sadaqah (ZIS) melalui media Counter BAZNAS, payroll system, jasa perbankan (transfer, phone dan internet banking), layanan e-commerce, dan jemputan dana zakat.

3. Layanan muzakki, terdiri dari konsultasi dan konfirmasi zakat, Nomor Pokok Wajib Zakat (NPWZ), Bukti Setor Zakat (BSZ) dan Laporan Donasi, SMS/email gateway, dan Muzzaki Corner.

PP No. 14 Tahun 2014 dalam pasal 1 ayat 2 bahwa BAZNAS merupakan institusi yang bertugas untuk melakukan pengumpulan dan pengelolaan dana zakat secara nasional. Selanjutnya pasal 1 ayat 6 bahwa undang-undang adalah UU. No. 23 Tahun 2011 tentang Pengelolaan Zakat. ${ }^{26}$ Ada tuntutan yang besar bagi BAZNAS untuk dapat menjadi organisasi yang dilandasi jiwa amanah dan profesional. Amanah dalam penghimpunan dan pendayagunaan zakat serta pelayanan muzakki; profesional dalam penyaluran dan pendistribusian zakat dan pemuliaan mustahik, amanah dalam fungsi pelayanan zakat, serta profesional dalam proses manajemen yang akuntabel dalam pengumpulan dan pendayagunaan zakat.

Teknologi informasi dapat digunakan untuk membantu pengelolaan zakat menjadi lebih transparan dan akuntabel. Pemanfaatan teknologi informasi terkait pengelolaan zakat yang dilakukan dapat diakses lebih mudah, cepat, dan efisien, sehingga pengelolaan zakat dapat lebih transparan dan memudahkan publik melakukan pengawasan. ZIS akan memudahkan pertanggungjawaban pengelolaan zakat. Selain itu dukungan pemerintah memiliki posisi yang sangat penting. Tanpa dukungan pemerintah akan sulit bagi BAZNAS untuk dapat maju dalam pengumpulan, pendayagunaan dan pendistribusian zakat di Kabupaten Gorontalo. Peningkatan angka pengumpulan, pendayagunaan dan pendisrtibusian tidak terlepas dari arahan langsung kepala daerah untuk mendorong masyarakat untuk berzakat kepada institusi pengelola zakat.

\section{Pasal 1.}

\footnotetext{
${ }^{26}$ Republik Indonesia, Peraturan Pemerintah Republik Indonesia Nomor 14 Tahun 2014, Bab I
} 
Restrukturisasi lembaga zakat menyesuaikan UU No. 23 Tahun 2011 yang konvensional kepada model tata kelola yang teratur sangat penting dilakukan untuk penguatan lembaga zakat di tanah air. Saat ini dengan regulasi yang sudah ada kiranya telah memberikan landasan kokoh bagi semua lembaga zakat resmi, meskipun oleh sebagain daerah belum bisa terselenggara secara optimal. ${ }^{27}$ Kebiasaan masyarakat dalam berzakat secara langsung saat ini sudah menjadi budaya yang kuat dalam masyarakat. Kondisi ini dirasakan menjadi kontra produktif dalam upaya mewujudkan tujuan pengelolaan zakat lembaga BAZNAS Kabupaten Gorontalo agar lebih efektif dan efisien serta berkontribusi terhadap peningkatan kesejahteraan masyarakat, khususnya kalangan mustahik. Untuk itu, perlu ada upaya yang sistematis untuk mendorong masyarakat agar mau berzakat melalui institusi amil.

Oleh karena itu, BAZNAS Kabupaten Gorontalo membentuk satu gerakan, gerakan pengumpul kesadaran muzakki yang dikenal dengan "Gerakan Tuntas Zakat." Hal ini menjadi satu langkah awal yang diambil pihak BAZNAS agar membentuk suatu perubahan yang baik bagi kesejahteraan masyarakat dan menuntaskan kemiskinan di Kabupaten Gorontalo. Gerakan Tuntas Zakat merupakan suatu bentuk dukungan dari pemerintah, juga sekaligus menjadi bentuk kerjasama antara Pemerintah, Kementerian Agama, dan BAZNAS Kabupaten Gorontalo. Program ini menginstruksikan kepada seluruh SKPD untuk melakukan pengumpulan zakat sejumlah 2,5\% dari pendapatan bersih sesuai amanah Perbup Kabupaten Gorontalo No. 1 Tahun 2016 tentang Teknis (Tata Cara) Pengumpulan Zakat di Lingkungan Pemerintah Kabupaten Gorontalo. Strategi yang dilakukan ini memang sasarannya mengarah pada jajaran SKPD Kabupaten Gorontalo, karena kebanyakan dari memang dianggap wajib dalam membayar zakat.

Strategi-strategi Gerakan Tuntas Zakat dilakukan, baik melalui media massa, media cetak, mendatangi individu perindividu, maupun mensosialisasi secara massal. Namun tidak semua lapisan masyarakat yang dapat dijangkau secara baik, sehingga menjadi kendalanya yaitu kurangnya tenaga yang terbatas. Di sinilah Kementerian Agama Kabupaten Gorontalo ikut terlibat dalam setiap penyuluhan ataupun sosialisasi

\footnotetext{
${ }^{27}$ Badan Amil Zakat Nasional Kabupaten Gorontalo, Rencana Strategis Badan Amil Zakat Nasional Kabupaten Gorontalo 2015-2020.
} 
yang dilakukan oleh BAZNAS Kabupaten Gorontalo. Kesemua usaha yang dilakukan akhinya perolehan dana zakat mengalami peningkatan yang cukup signifikan setelah Gerakan Tuntas Zakat dijalankan.

Kendala lainnya adalah kebijakan pemerintah yang selama ini hanya sebatas himbauan dan sosialisasi, belum ada langkah paksa ataupun sanksi bagi orang yang tidak membayar dan menunggak dalam penyetoran dana zakat. Padahal sebenarnya potensi dana zakat di Kabupaten Gorontalo sangat besar sekitar \pm 5 miliar setiap tahunnya, namun yang dicapai baru sekitar \pm 2 miliar saja pertahunnya. Itu sudah keseluruhan baik dana zakat yang dihimpun dari muzakki perorangan, muzakki kelembagaan ataupun instasi-instasi dalam jajaran SKPD Kabupaten Gorontalo.

Juga ditemukan bahwa pihak BAZNAS Kabupaten Gorontalo saat ini masih menunggu regulasi aturan baru yang akan disahkan oleh Majelis Ulama Indonesia (MUI) dan Kementerian Agama tentang pengumpulan dana zakat, yang memiliki wewenang langsung memotong dari gaji, sekalipun saat ini gaji yang diterima oleh ASN tidak lagi diterima secara tunai, melainkan melalui rekening masing-masing, sehingga aturan ini menjadi langkah paksa untuk muzakki membayar zakat serta harapannya dengan adanya aturan baru ini akan mempengaruhi perolehan dana zakat di Kabupaten Gorontalo.

Mengenai strategi pengelolaan zakat, berhasil atau tidaknya sangat tergantung pada amil zakat yang mengelolah zakat tersebut. Untuk menghadapi kesulitan dalam pengelolaan zakat, BAZNAS Kabupaten Gorontalo memiliki strategi sebagai berikut:

1. Sosialisasi UU No. 1 Tahun 2016 tentang Pengelolaan Zakat

BAZNAS Kabupaten Gorontalo melaksanakan sosilisasi UU No. 1 Tahun 2016 tentang Pengelolaan Zakat, kepada para tokoh masyarakat dan pada para aparat sipil negara di tiap kantor milik pemerintah. Mereka melakukan sosialisasi dari kantor ke kantor dengan sebelumnya telah mendapat izin dari bupati kabupaten Gorontalo.

2. Penyuluhan

Penyuluhan akan kesadaran berzakat dilakukan oleh BAZNAS Kabupaten Gorontalo kepada masyarakat umum melalui khutbah jum'at yang dilakukan tim Pengurus BAZNAS Kabupaten Gorontalo. 
3. Akuntabilitas Pelaporan

BAZNAS Kabupaten Gorontalo melakukan kegiatan pendistribusian maupun sosialisasi tiap kegiatan yang sudah di dokumentasikan ke dalam akun resmi BAZNAS di sosial media, sehingga semakin memberi keyakinan kepada masyarakat untuk membayarkan zakatnya melalui BAZNAS Kabupaten Gorontalo.

4. Penerbitan Kartu Anggota Muzakki

BAZNAS Kabupaten Gorontalo menerbitkan Kartu Anggota Muzakki agar semua ASN di Kabupaten Gorontalo membayarkan zakatnya tercatat dan menjadi pedoman pembagian laporan penyaluran dana zakat per-triwulan.

5. Pembayaran Zakat melalui Bank

BAZNAS Kabupaten Gorontalo memiliki kerjasama dengan pihak perbankan agar para wajib zakat dapat memberikan dana zakat, infak, dan sedekah melalui fasilitas perbankan, misalnya transfer, pindah buku, auto debet, ATM, phone banking ataupun fasilitas lain yang disiapkan pihak bank. Pihak bank yang bekerjasama dengan BAZNAS Kabupaten Gorontalo, yaitu: Bank Mandiri, Bank Rakyat Indonesia, dan Bank Pembanguan Daerah (BPD) SULUTGO.

6. Aksi Jemput Zakat

BAZNAS Kabupaten Gorontalo melakukan upaya menjemput secara langsung ke rumah wajib zakat. Program ini dilakukan oleh petugas zakat dengan menghubungi call center/costumer service pada nomor (0435) $881027 .^{28}$

Berbagai upaya dan strategi yang dilakukan oleh BAZNAS Kabupaten Gorotalo pada intinya adalah memberikan kesadaran akan pentingnya mengeluarkan zakat, sehingga dapat membantu pihak-pihak yang wajib menerima zakat dan dapat meningkatkan taraf perekenomian pihak-pihak penerima zakat tersebut.

\section{Pasang Surut Dampak "Gerakan Tuntas Zakat" di Kabupaten Gorontalo}

Berbagai isu strategis yang dihadapi oleh BAZNAS Kabupaten Gorontalo dalam hal pengelolaan zakat dan dana sosial keagamaan lainnya antara lain:

\footnotetext{
${ }^{28}$ Ibid.
} 
1. Isu Internal

Isu ini terkait dengan isu yang dihadapi pihak BAZNAS Kabupaten Gorontalo secara internal kelembagaan, antara lain:

a. Sebagai lembaga pemerintah non struktural yang dibentuk oleh pemerintah, maka pemerintah berperan dalam menguatkan badan tersebut sebagai bagian yang tidak terpisahkan dari Pemerintah Kabupaten Gorontalo. Oleh sebab itu perlunya peningkatan sinegritas dengan antara BAZNAS Pusat, BAZNAS Provinsi dan BAZNAS Kabupaten Gorontalo dengan Pemerintah Kabupaten Gorontalo untuk menguatkan kedudukan organisasi pengelolaan zakat dan perannya.

b. Keterbatasan profesionalisme SDM para amil zakat dan masih rendahnya insentif yang diterima oleh amil hanya tergantung pada bagian 1/8 (seperdelapan) dari zakat, kalau zakat meningkat maka insentif meningkat, kalau zakat menurun, maka insentif menurun. Sementara kinerja amil beraktivitas di BAZNAS Kabupaten Gorontalo, sudah disamakan dengan Instansi Pemerintah masuk jam 08.00 Wita keluar 16.00 Wita, bahkan sampai malam hari, kalau pelayanan muzakki/mustahik belum selesai, walaupun BAZNAS Kabupaten Gorontalo sempat menerima bantuan dari APBD dan APBN serta bantuan dari Kantor Wilayah Kementrian Agama Provinsi Gorontalo.

c. Aktivitas pengumpulan zakat yang beroperasi setiap hari (office hour) untuk memberikan pelayanan yang prima kepada muzakki dan mustahik menyebabkan beban operasional yang besar.

d. Belum maksimalnya pemanfaatan teknologi dan bank data, seperti media sosial (facebook, twitter, blog, web, dan lain-lain) sebagai pusat aktivitas kelas menengah belum secara berkala di maintance secara baik. Penggunaan system terintegritas satu bagian dengan bagian lainnya belum secara optimal dilakukan sedangkan keberadaan database merupakan tolak ukur dari kemajuan Pengelolaan Zakat sebuah lembaga.

2. Isu Eksternal

Isu ini terkait isu di luar kelembagaan yang dihadapi BAZNAS Kabupaten Gorontalo, antara lain: 
a. Pertumbuhan Kelas Menengah dan Potensi Zakat di Kabupaten Gorontalo

Mayoritas penduduk Kabupaten Gorontalo adalah beragama Islam, yaitu \pm 98\% dengan pertumbuhan ekonomi Kabupaten Gorontalo terus meningkatkan di atas ratarata pertumbuhan ekonomi nasional, dan kelas menengah Kabupaten Gorontalo terus bertambah, menjadikan potensi zakat Kabupaten Gorontalo berkembang. Potensi zakat meningkat Rp. 50.000.000 - Rp.70.000.000 per tahun. Dengan adanya sosisalisasi zakat terus menerus didukung oleh Pemerintah Kabupaten Gorontalo meningkat lagi menjadi Rp. 70.000.000 - Rp.131.000.000 per bulan.

b. Kemiskinan di Kabupaten Gorontalo

Angka kemiskinan di Kabupaten Gorontalo masih tinggi yang berkisar sampai 21\%. Hal ini menjadi prioritas bagi BAZNAS dan Pemerintah Kabupaten Gorontalo dalam memberikan bantuan dan memberdayakan masyarakat dhuafa' sehingga dapat mandiri dan sejahtera. Di lain pihak BAZNAS Kabupaten Gorontalo telah diketahui oleh masyarakat sebagai pengelola dana zakat, sehingga permohonan bantuan sosial lainnya banyak ditujukan ke BAZNAS Kabupaten Gorontalo.

c. Kepercayaan terhadap BAZNAS sebagai Lembaga Pemerintah Non Struktural

Tingkat kepercayaan kepada BAZNAS daerah di Indonesia pada umumnya dan di Kabupaten Gorontalo disadari masih rendah dikarenakan BAZNAS adalah lembaga pemerintah non struktural yang dibentuk oleh Pemerintah. Masyarakat menganggap pengelolaan kurang amanah, lambat, kurang kreatif, kurang professional masih menjadi kesan pada sebagian besar BAZNAS Kabupaten Gorontalo, sekalipun penataannya dilakukan terus-menerus, guna menghilangkan kesan tersebut. Patut dibanggakan BAZNAS Kabupaten Gorontalo sudah baik dalam pengelolaan zakat. Hal itu dibuktikan Tahun 2011 BAZNAS Kabupaten Gorontalo piagam penghargaan terbaik 2 (dua) dalam pengelolaan zakat dari Kepala Kantor Wilayah Kementreian Agama Provinsi Gorontalo. Juga pada bulan Agustus 2016, BAZNAS Kabupaten Gorontalo mendapat kunjungan dari BAZNAS Pusat atas pengelolaan zakat secara profesional, transparansi, dan akuntabel.

d. Dukungan Politik dari Pemerintah Daerah 
Dukungan Kepala Daerah dan perangkat daerah untuk pengelolaan zakat di tingkat lokal memiliki posisi yang sangat penting. Ini juga terjadi di Kabupaten Gorontalo bahwa tanpa dukungan Kepala Daerah dan perangkat-perangkat daerah, maka akan sangat sulit bagi BAZNAS Kabupaten Gorontalo untuk dapat maju. Adanya dukungan dari pemerintah daerah misalnya pada waktu BAZNAS Kabupaten Gorontalo dipimpin Asisten Ekonomi dan Pembangunan Setda Kabupaten Gorontalo Drs. Hen Restu mengadakan Studi banding di Baznas Provinsi Sumatra Barat dan pada tahun 2015 penerimaan zakat maal setiap bulan \pm Rp. 1.000.000.000.

e. Peran Penting Media Massa

Media massa sebagai media strategis dalam pembangunan kesadaran masyarakat berzakat, dan sosialisasi pemberdayaan zakat, sehingga pengelolaan zakat terpublikasikan kepada publik secara transparan. Namun kendala utama yang dihadapi BAZNAS Kabupaten Gorontalo dari segi pendanaan untuk biaya tersebut (operasional lembaga) hanya mengandalkan dari hak amil sebagian besar. Biaya lain yang diharapkan dapat menunjang berasal dari APBD/APBN setiap tahunnya terkadang ada dan terkadang tidak, kalau pun ada itupun masih terbatas. Olehnya itu berdasarkan temuan di lapangan bahwa tantangan dan hambatan BAZNAS Kabupaten Gorontalo untuk mengoptimalkan pengelolaan zakat dalam Gerakan Tuntas Zakat antara lain:

1. Kurangnya tingkat kesadaran umat Islam tentang zakat sebagai ibadah mahdha (ibadah pokok) sama dengan shalat, puasa dan haji.

2. Tingkat kepercayaan muzakki yang masih rendah terhadap pihak BAZNAS sebagai lembaga pengelolaan zakat.

3. Masyarakat yang belum memahami secara jelas terkait peran BAZNAS.

4. Terbatas Sumber Daya Manusia (SDM) pengurus dan staf BAZNAS Kabupaten Gorontalo dalam memanfaatkan teknologi.

5. Terbatasnya sarana dan prasarana yang memadai, termasuk Kantor Sekretariat BAZNAS Kabupaten Gorontalo sampai dengan saat ini belum memiliki Kantor Sekretariat definitif.

6. Masih terdapatnya pengurus UPZ yang kurang amanah.

7. Gaji ASN yang minus akibat diserap oleh sebagai kredit dan transaksi lainnya. 
8. Masih terbatas sosialisasi zakat.

9. Kebijakan pemerintah yang masih sebatas himbauan, belum ada paksaan ataupun sanksi bagi muzakki yang belum membayar zakat.

10. Kemauan, keinginan dan keikhlasan untuk berzakat belum sepenuhnya, akibat dari pengetahuan syari'at Islam masih minim sehingga lebih banyak memprioritaskan kehidupan dunia dan sehingga bekal ke akhirat.

\section{E. Kesimpulan}

Optimalisasi gerakan mengumpul zakat dalam meningkatkan kesadaran muzakki di BAZNAS Kabupaten Gorontalo nyatanya belum membuahkan hasil yang maksimal. Tingkat kesadaran adalah masyarakat perlu memahami dan menyadari peran dan fungsi BAZNAS dalam pengelolaan zakat, terutama dalam aktivitas pengumpulan. Walaupun ada masyarakat yang sadar untuk membayar zakat hanya saja penyaluran dana zakat melalui BAZNAS belum keseluruhan, sehingga hal inilah yang dianggap bahwa muzakki belum membayar zakat dan belum mencapai nisabnya, padahal masyarakat sudah terbiasa menyalurkan dana zakat langsung ke orang yang dianggap layak menerima (mustahik) tanpa melalui perantara.

Upaya BAZNAS Kabupaten Gorontalo dalam meningkatkan kesadaran muzakki yaitu dengan membentuk satu gerakan pengumpul zakat yang dikenal dengan Gerakan Tuntas zakat dimana salah satu strategi yang dilakukan dengan mendatangi muzakki secara langsung untuk memudahkan muzakki menyalurkan dana zakatnya. Gerakan ini lebih banyak merangkul Pemerintah dan SKPD Kabupaten Gorontalo, karena memang kenyataanya sasaran pihak Baznas yakni SKPD Kabupaten yang memang dianggap wajib menjadi muzakki. Terkait kebijakan pemerintah, selama ini hanya sebatas himbauan dan sosialisasi. Belum ada langkah paksa ataupun sanksi bagi orang yang tidak membayar dan menunggak dalam penyetoran dana zakat. Padahal sebenarnya potensi dana zakat di Kabupaten Gorontalo sangat besar sekitar \pm 5 miliar setiap tahunnya, namun yang dicapai baru sekitar \pm 2 miliar saja pertahunnya. Itu sudah keseluruhan baik dana zakat yang dihimpun dari muzakki perorangan, muzakki kelembagaan ataupun Instasi-instasi dalam hal ini jajaran SKPD Kabupaten Gorontalo. 


\section{Daftar Pustaka}

Badan Amil Zakat Nasional Kabupaten Gorontalo. Rencana Strategis Badan Amil Zakat Nasional Kabupaten Gorontalo 2015-2020.

Departemen Agama RI, Pedoman Pengelolaan Zakat. Jakarta: Direktorat Pengembangan Zakat dan Wakaf, Ditjen Bimas Islam dan Penyelenggaraan Haji, 2004.

Djuanda, Gustian. Pelaporan Zakat Pengurang Pajak Penghasilan. Jakarta: PT. Raja Grafindo PERSADA, 2006.

Hasan, Ali. Zakat dan Infak. Jakarta: Kencana Prenada Media, 2005.

Huda, Mahmud. "Peran Pemerintah dalam Pengelolaan Zakat Menghadapi Pasar Tung gal Asean 2015," Prosiding Seminas Competitive Advantage, Vol. 1 No. 1, 2011

Inayah, Gazi. Teori Komprehensif tentang Zakat dan Pajak. Yogyakarta: PT. Tiara Wacana Yogya, 2003.

Kementerian Agama RI. Ummul Mukmin: Al-Qur'an dan Terjemahan untuk Wanita. Jakarta: Wali, 2010.

Mursyidi, Akuntasi Zakat. Bandung: PT. Remaja Rosda Karya, 2003.

Qadir, Abdurrahman. Zakat dalam Dimensi Mahdah dan Sosial. Jakarta: Raja Grafindo Persada, 1988.

Rasyid, Rahmawati A. "Studi Pengelolaan Zakat Fitrah di Kecamatan Tibawa Kab. Gorontalo," Skripsi . Gorontalo: Fakultas Syariah dan Ekonomi Islam, 2010.

Republik Indonesia. Peraturan Pemerintah Republik Indonesia Nomor 14 Tahun 2014.

Ash-Shiddieqy, Teungku Muhammad Hasbi. Pedoman Zakat. Semarang: PT. Pustaka Rizki Putra, Semarang, 2006.

Al-Syahatah, Husein. Akuntasi Zakat. Jakarta: Pustaka Progresif, 2004.

Asy-Syaukani, Imam. Nailul Authar. Bairut: Dar Ibn Hazm, 2000.

Tasrifin, M. "Studi Pelaksanaan Pengelolaan Zakat di Lembaga Pengembangan Dana Umat Sultan Agung LPDU-Sa Semarang," Skripsi. Semarang: Unisula, 2008.

Zallum, Abdul Qadim. Al-Amwal fi Dawlah al-Khilafah. Bairut: Darul 'Ilmi li alMalayin, 1983

Al-Zuhayly, Wahbah. Zakat Kajian Berbagai Mazhab. Bandung: Remaja Rosdakarya, 2005.

http://www.beritasatu.com/blog/ekonomi/2764-optimalisasi-pengelolaan-dan-\%09 regulasi-zakat.html 